\title{
sciendo
}

CIVIL AND ENVIRONMENTAL ENGINEERING REPORTS

E-ISSN 2450-8594

CEER 2018; 28 (2): 101-111

DOI: 10.2478/ceer-2018-0022

Original Research Article

\section{STATIC EQUILIBRIUM PATHS OF STEEL-CONCRETE COMPOSITE BEAM STRENGTHENED UNDER LOAD}

\author{
Piotr SZEWCZYK ${ }^{1}$, Maciej SZUMIGAŁA ${ }^{2}$ \\ ${ }^{1}$ West Pomeranian University of Technology, Szczecin, Poland \\ ${ }^{2}$ Poznan University of Technology, Poznań, Poland
}

\begin{abstract}
The paper presents exemplary static equilibrium paths of an element strengthened while under load. A steel-concrete composite beam was analyzed. The study discusses the effect of strengthening method, initial load values, welding stress, concrete shrinkage and introduction of additional control of distortion state on the course of static equilibrium path. Results calculated in numerical FEM simulation were verified with experimental data and were found to be consistent.
\end{abstract}

Keywords: strengthening, composite beams, residual stress, distortions, FEM

\section{INTRODUCTION}

Static equilibrium path, e.g. in force-displacement or moment-curvature relations, is a universal and synthetic method that describes behavior of an element or civil engineering structure while under changing interactions. Briefly, static equilibrium path is a graphic record of the element's or the structure's equilibrium history. It clearly shows e.g. the relation between load and the resulting deformation or displacement.

\footnotetext{
${ }^{1}$ Corresponding author: West Pomeranian University of Technology, Faculty of Civil Engineering and Architecture, Avenues Piastów 50, 70-311 Szczecin, Poland, e-mail: szewczyk@zut.edu.pl 2 Corresponding author: Poznan University of Technology, Faculty of Civil and Environmental Engineering, Institute of Structural Engineering, ul. Piotrowo 5, 60-965 Poznań, Poland, e-mail: lukasz.polus@put.poznan.pl, tel.+48616652098
} 
When a structure is strengthened by extending the cross-section, stiffness gets changed and consequently the (initial) inclination angle of static equilibrium path is also changed. In vast majority of cases, load applied to a structure cannot be completely relieved so that the strengthening element would start interaction already at the initial stage of loading the strengthened element. Complete load release is often impossible or economically not viable. It is therefore fair to assume that any structure that is being strengthened is already under certain load. Hence, the inclination angle of static equilibrium path undergoes a saltatory change the moment strengthening occurs (p.A Figure 2).

The same assumption was made in the present work. The strengthening element starts to work together when the strengthened structure already shows a certain (sometimes substantial) level of stress. Another element that "complicates" the course of static equilibrium path is the effect of residual stress, in the form of concrete shrinkage and residual welding stress. That kind of stress affects stiffness and deflection values of the strengthened structure, which is also accounted for in the present paper.

The problem was analyzed numerically and experimentally. Results are part of a wider research program on how to determine effectiveness of strengthening for structures which are under load.

\section{EXPERIMENTAL MODEL}

Analysis and experiments were conducted on a $5.0 \mathrm{~m}$ steel-concrete composite beam with a cross-section shown in Fig.1. The beam was analyzed as a simply supported beam and the cross-section was designed so that the elastic neutral axis was as close as possible to the connection plane.

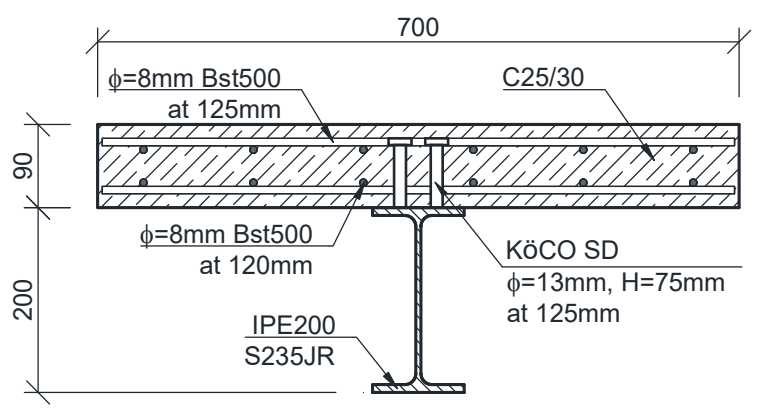

Fig. 1. Cross-section of composite beam

In line with these assumptions, two types of research beams were made. First, a 3D numerical FEM model was developed, accounting for geometric nonlinearities, nonlinear physical laws of materials (Concrete Damage Plasticity model for concrete, elastic-plastic model with hardening for steel), connection 
flexibility and for the effect of residual stress. Next, to verify numerical models, experimental models were made which would later be strengthened in the experiment.

\section{STATIC EQUILIBRIUM PATHS}

\subsection{Path determination}

Figure 2 shows an exemplary static equilibrium path of an element strengthened while under load (force shall be read as a total load on beam, displacement as a mid-span defletion). The dotted line shows a reference static equilibrium path of a beam without strengthening. Up to the time when strengthening (A) was made, both paths overlap. At point A, strengthening is realized through extending the cross-sectional area. The steel part of the cross-section can be extended by welding in additional sheet metal or a hot rolled profile [1]. The reinforced concrete part can be reconstructed by increasing the thickness of the slab (concrete overlay) [5]. Both solutions increase stiffness of the element, i.e. the applied load would cause smaller displacement that it would have done before strengthening. The static equilibrium path shows it as a change of inclination angle in the graph relative to the $\mathrm{x}$ axis. Segment $\mathrm{AB}$ is the elastic range of operation of the structure after strengthening. Then plasticity is developed until a fully plastic joint is achieved in point $\mathrm{C}$. Finally, at point $\mathrm{D}$ the element is destroyed.

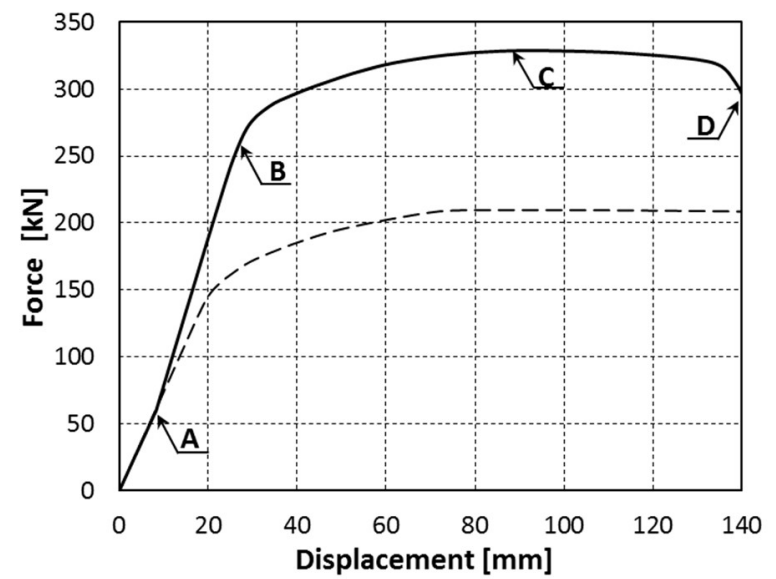

Fig. 2. Static equilibrium path of an element strengthened while under load

Point $\mathrm{A}$ is the most interesting place in the analyzed static equilibrium path. It is here that the strengthening element joins in. The initial state must be understood as the curvature of partly loaded strengthened element. Moreover, any reconstruction or extension of a cross-section inevitably means that the 
cross-section parts which are strengthened will be permanently connected with the strengthening part. In the reconstruction of the steel part, it is necessary to weld elements. In the reconstruction of the concrete part, two layers of concrete must be connected. Both welding and shrinkage of a newly placed concrete mix create additional residual stress. Analysis below discusses how such type of stress and deformation affect the static equilibrium path at point $\mathrm{A}$.

\subsection{Welding shrinkage}

The steel part of the cross-section was reconstructed by welding a 10x120x3300 mm flat bar to the bottom flange of IPE200 profile. In a study [3], a method of selecting optimal dimensions of strengthening sheet metal was presented. The connection was realized using continuous fillet welds, whose distribution is shown in Fig. 3.

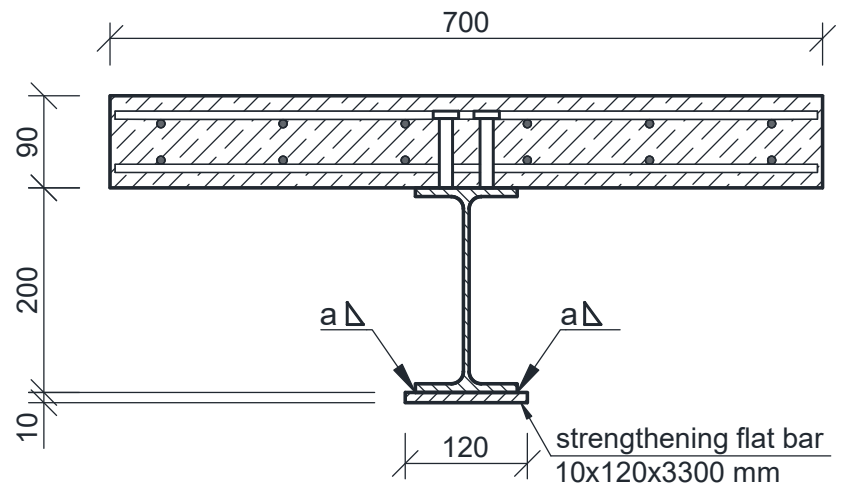

Fig. 3. Strengthening by welding a flat bar to the bottom flange of IPE200 profile

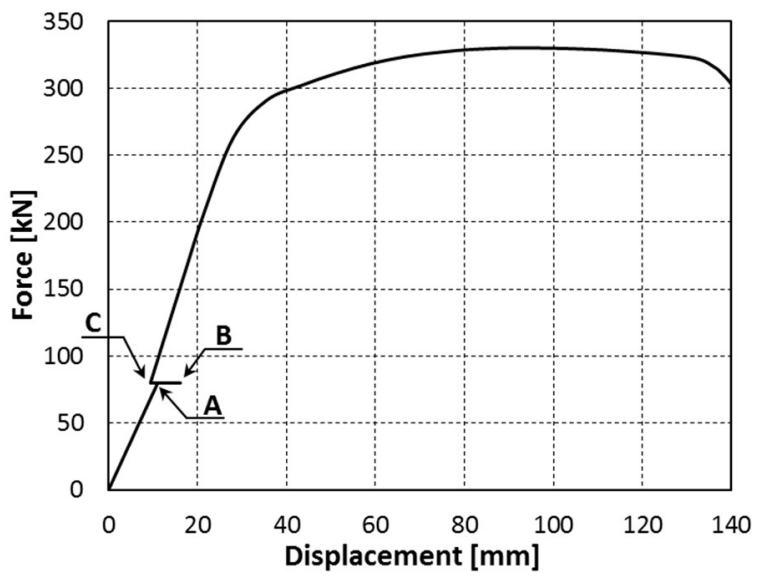

Fig. 4. Static equlibrium path of beam strengthened by welding a flat bar 
Fig. 4 shows the static equilibrium path of a beam strengthened by welding in a flat bar, accounting for the effect of welding stress. When in under-load state, which is defined by point $\mathrm{A}$, strengthening sheet metal is introduced under the I-section and then the connection is welded. Heat energy released during welding causes local weakening of the cross-section, through plastic softening of some steel fibers, and changes the geometrical dimensions of the elements due to steel linear thermal expansion. All this results in increased beam deflection at constant load, which is represented by point B in Fig. 4. In the next stage, the element is cooling. As a result, deflection value is negative which can be seen in point $C$. The last stage is the introduction of increased operational load until the element is destroyed.

The welding of an already existing structure always poses the threat that steel in the vicinity of welded connection can change its properties for the worse. However, the presented localization of point $\mathrm{C}$ can also offer some benefits resulting from welding shrinkage. Given the distribution of connections, their shrinkage causes some sort of beam tension and reduces deflection values of the strengthened element. The distribution of points $\mathrm{B}$ and $\mathrm{C}$ on the equilibrium path, i.e. displacement during welding and cooling, is clearly dependent on preloading levels. When preloading increases, momentary weld displacement increases and permanent welding deformation decrease [4].

\subsection{Concrete shrinkage}

The alternative solution is to reconstruct the reinforced concrete part by adding an extra layer of concrete (e.g. high strength concrete) with height $h_{b}$ placed on the existing reinforced concrete slab, as shown in Fig. 5.

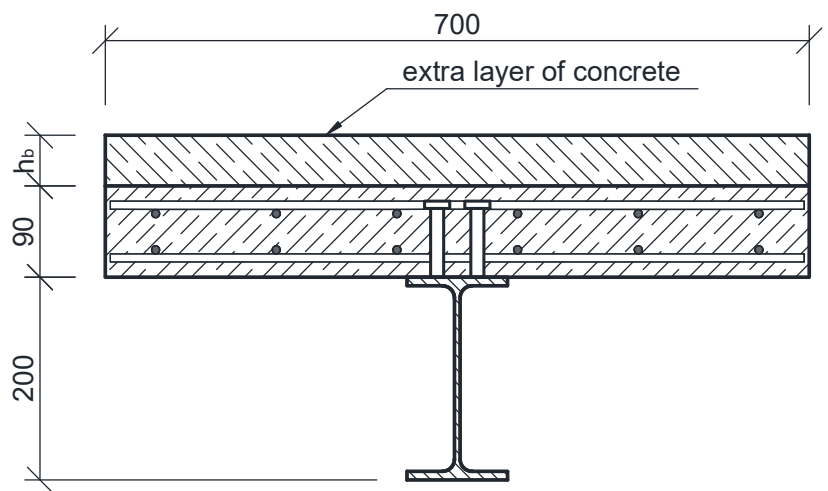

Fig. 5. Strengthening by adding an extra layer of concrete

The method has many limitations. To ensure interaction between the two concrete slabs, the existing and the strengthening ones, any finishing layers on top of the 
slab must be removed, surface needs appropriate pretreatment and sometimes additional mechanical connectors must be used. Additional problems arise; dead load significantly increases (mass increase can be minimized with HPC - high performance concrete), time which is necessary to achieve required strength of the newly placed concrete mix, and concrete shrinkage which develops over time. Despite these problems, this type of strengthening is technically possible and when, for example, there is no access to the lower part of the structure, it can be taken into consideration. Inevitably, whether or not the investment is profitable requires in-depth analysis.

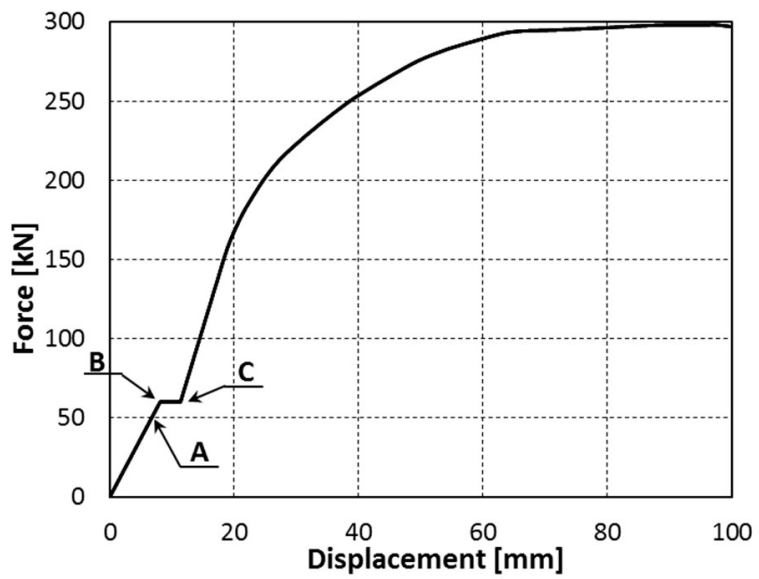

Fig. 6. Static equlibrium path of beam strengthened by adding an extra layer of concrete

The problem is presented in Fig. 6. Point A is the state before strengthening. Since all finishing layers must be removed, the possibility of strengthening while under load is markedly narrowed. Some part of the load can be found under the concrete slab, e.g. as air conditioning installations, lighting or suspended ceilings but it can hardly be a considerable percentage of the overall load bearing capacity of the element. Point B lies on the extension of the initial direction of the static equilibrium path and symbolizes the state of the structure the moment after placing of the additional strengthening slab $\left(h_{b}=60 \mathrm{~mm}, \mathrm{C} 25 / 30\right.$ concrete). At first, the new concrete mix will not carry any loads. Contrary to that, it will be additional load, thus increasing displacement of strengthened concrete. Over the next days, weeks and months, shrinkage of the new layer of concrete will develop. If the concrete overlay is placed in the upper part of the cross-section, shrinkage will increase displacement, which was represented as the horizontal segment BC. The position of point $\mathrm{C}$ depends mainly on the length of time between concrete placing, laying new finishing layers and introduction of increased operational load. To sum up, extension of the concrete part will result in increased deflection, caused by increased dead load and happening over time concrete shrinkage. 


\subsection{Distortion control}

The above presented equilibrium paths assumed strengthening of the structure while under load while maintaining deformation freedom of the strengthened element. This means that at each stage of reconstruction the beams operates in the initial mode (e.g. as simply supported beam) and has freedom regarding its displacements caused by welding or concrete shrinkage. It also means that stress strain state and displacement before strengthening would eventually determine the economic viability of the strengthening process. Even if yielding is assumed to be possible at the stage of designing, the serviceability limit state may be a limitation which would make it impossible to increase load leading to plastic stress redistribution.

The introduction of additional intermediate supports during all the works could be the solution. The range in which supports operate is diverse. The simplest solution is to block additional displacements. Another way is to use so-called active supports, which introduce their own displacement direction, contrary to the existing direction (e.g. by hydraulic cylinders). At this point, several solutions are possible. Option one -partial elimination of initial displacement. Two elimination of the initial deflection value. Three - introduction of reverse deflection. In option three, deflection value should be planned carefully, not to exceed tensile stress limit in the upper fibers of the concrete slab and not to scratch it. It must not be forgotten that in this solution the bottom flange of the steel beam is compressed. It has an adverse effect on changes of deformation and welding stress and on its stability.

The use of additional supports raises another question as for their number and distribution along the beam's length. At the same level of excited displacement, it is possible to obtain different relations of force decrease to displacement decrease by controlling the distribution of supports. A similar example is when you change the position of forces applied to a simply supported beam. From the engineering point of view, at the discussed load, the use of additional supports should cause distribution of moments possibly close to a parabola of evenly distributed load.

Successive figures present exemplary static equilibrium paths of the strengthened beam, taking into consideration all previously discussed assumptions: strengthening conducted while under load, residual stress and distortion control. Figure 7 shows an exemplary static equilibrium path of a beam strengthened with sheet metal, as described in 3.2. Additionally, partial stress relief was introduced with active supports. Owing to many factors affecting the form of the path, the vicinity of the point where strengthening is placed was enlarged and characteristic places were defined with successive points. 
Point A characterizes the level of loads and displacements at which strengthening is supposed to be made. At point A the strengthening sheet metal should be placed under the beam and additional supports introducing displacement direction opposite to deflection. Segment AB stands for resulting displacements. Its angle of inclination depends on the spacing of active supports. Decrease of spacing decreases the inclination angle relative to displacement axis. In this case, segment $\mathrm{AB}$ is above the initial force-displacement relation (as seen in the figure). There is such spacing of supports that would cause load relief on the axis overlapping the load axis. Increase of the spacing between intermediate supports results in segment $\mathrm{AB}$ being below the initial equilibrium path.

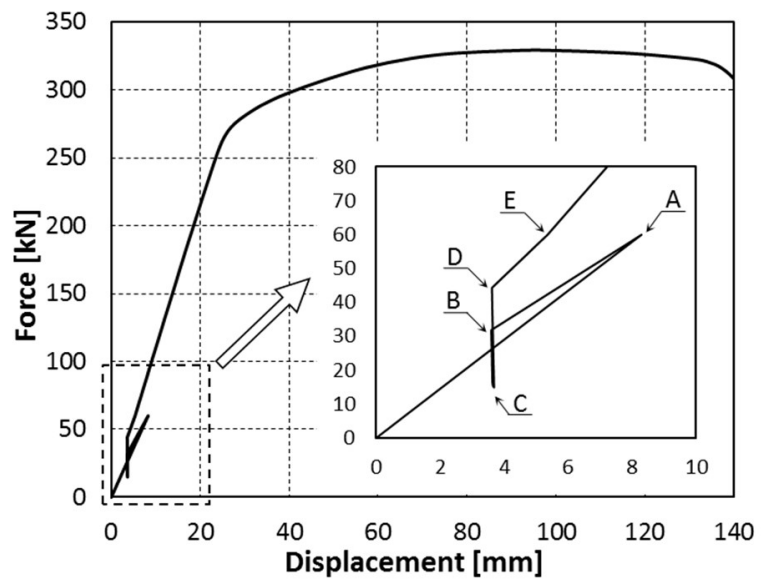

Fig. 7. Static equlibrium path of beam strengthened by welding a flat bar and distortion control

At point B welding begins. During welding, the beam cannot freely deform since it rests on additional supports. If it cannot displace, some change must result on the force axis. Lower fibers of the strengthened beam are extended during welding and stiffness of the cross-section decreases. Therefore, force acting in the element decreases, which can be seen in segment BC. At point $\mathrm{C}$ welding is finished and the structure starts to cool down. When temperature decreases, welding shrinkage occurs and force in the element increases (segment CD). When the cooling process is completed (at point D), intermediate supports are no longer necessary and can be removed. The effect of support removal is visible in segment DE as displacement increase and load returning to the level from before strengthening. Owing to strengthening, segment DE has greater inclination angle than that of the initial segment OA, which shows that stiffness of the element increased. From point $\mathrm{E}$, there is further increase of the force linked to increased operational load and further development of the equilibrium path is identical to that presented above. 
A similar static equilibrium path was also obtained for the reconstruction of the concrete part. An exemplary equilibrium path of a beam strengthened with an additional layer of concrete, $60 \mathrm{~mm}$ thick, is shown in Fig. 8. Segment AB, similarly to the example above, shows the effect of using active supports. In point $\mathrm{B}$, an additional reinforced concrete slab is made. A comprehensive analysis shows that following concrete placing on the slab, point B should be corrected by $5 \mathrm{kN}$, i.e. by the dead load of the new concrete mix. After concrete placing and once setting has started, shrinkage starts to develop in the new concrete. It is symbolized by segment BC. In the presented case, the simplest solution was assumed, i.e. all shrinkage occurs when the beam is supported. The reality is more complicated and segment $\mathrm{BC}$ can be broken down into several segments. It can be assumed that additional support was removed as early as several days after concrete placing and that shrinkage develops in a beam operating as a simply supported beam. Segment CD stands for removal of additional supports and thus displacement increase and force returning to the level from before strengthening. Further development of the equilibrium path is typical, as presented above.

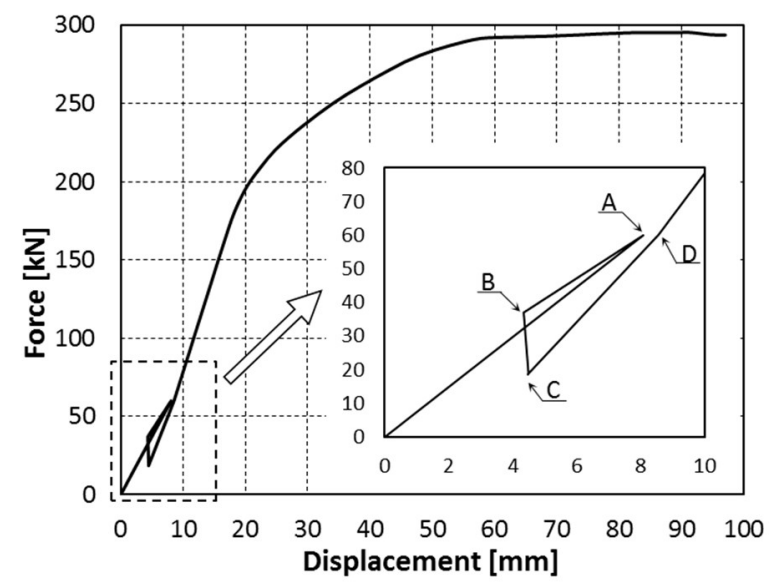

Fig. 8. Static equlibrium path of beam strengthened by adding an extra layer of concrete and distortion control

\section{CONSLUSIONS}

Analysis of the static equilibrium paths presented above shows very well that the process of strengthening a structure while under load is characterized by many design variables. The problem is even more complicated if the element is made up of more than one material, as is the analyzed steel-concrete composite beam. The physical experiment of strengthening the beam while under load [2] on models in large technical scale enabled verification of the presented methods of 
analyzing strengthening of steel-concrete composite structures with the above presented graphs of equilibrium paths. Fig. 9 shows that results of numerical FEM analysis (the dotted line) are consistent with experimental data obtained from three identical physical models P1, P2 and P3 (the solid lines).

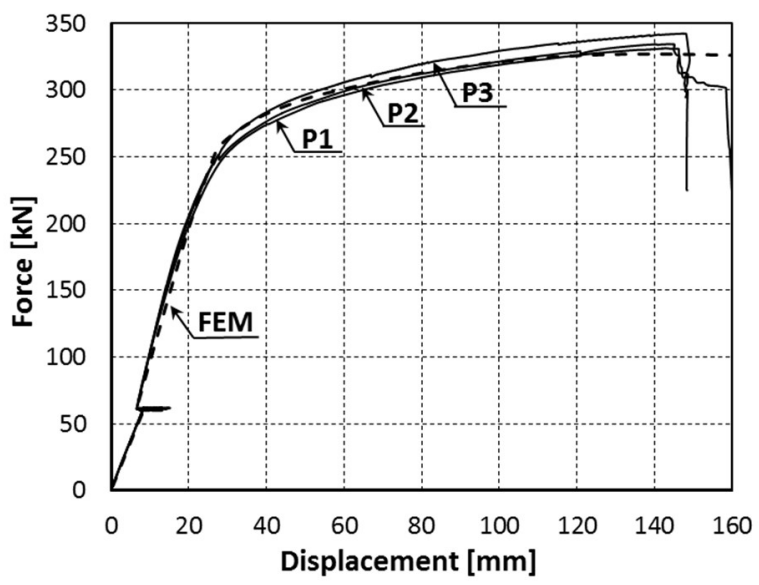

Fig. 9. Comparison between en empirical and numerical static equlibrium paths

To sum up, static equilibrium paths can be very helpful in the analysis and design of structural strengthening, particularly in case of composite structures.

\section{REFERENCES}

1. Bródka J.: Przebudowa i utrzymanie konstrukcji stalowych, Mostostal-Projekt S.A., Politechnika Łódzka, Warszawa/Łódź 1995.

2. Szewczyk P.: Wzmacnianie pod obciazieniem belek zespolonych stalowobetonowych $w$ eksperymencie numerycznym $i$ fizycznym, Rozprawa Doktorska, Zachodniopomorski Uniwersytet Technologiczny w Szczecinie, Szczecin 2016.

3. Szewczyk P., Szumigała M.: Numerical modelling of steel-concrete composite beams strengthening process, Civil And Environmental Engineering Reports, nr 19(4)/2015, s. 99-110.

4. Szewczyk P., Szumigała M.: Welding deformation in a structure strengthened under load in an empirical-numerical study, Advances in Mechanics: Theoretical, Computational and Interdisciplinary Issues, Taylor \& Francis Group, s. 563-566, London 2016.

5. Urban T., Wzmacnianie konstrukcji żelbetowych metodami tradycyjnymi, Wydawnictwo naukowe PWN SA, Warszawa 2015. 


\section{ŚCIEŻKI RÓWNOWAGI STATYCZNEJ STALOWO-BETONOWEJ BELKI ZESPOLONEJ WZMACNIANEJ POD OBCIĄŻENIEM}

\section{Streszczenie}

$\mathrm{W}$ pracy zaprezentowano przykładowe ścieżki równowagi statycznej elementu wzmacnianego pod obciążeniem. Analizie poddano belkę zespoloną stalowo-betonową. Omówiono wpływ metody wzmacniania, wartości obciążeń wstępnych, naprężeń spawalniczych, skurczu betonu oraz wprowadzenia dodatkowego sterowania stanem dystorsji na przebieg ścieżki równowagi statycznej. Wyniki uzyskano na drodze symulacji numerycznych MES a następnie ich słuszność zweryfikowano w badaniach doświadczalnych.

Słowa kluczowe: wzmacniania, belki zespolone, naprężenia rezidualne, dystorsje, MES

Editor received the manuscript: 9.11.2017 